\title{
Transient IGF-I Gene Expression during the Maturation of Functionally Related Central Projection Neurons
}

\author{
Carolyn A. Bondy \\ Developmental Endocrinology Branch, National Institute of Child Health and Human Development, National Institutes of \\ Health, Bethesda, Maryland 20892
}

Insulin-like growth factor I (IGF-I) is a monomeric peptide with significant homology to proinsulin. IGF-I has a number of potent effects on cultured neural tissue, including the stimulation of mitosis in sympathetic neuroblasts; the promotion of neurite outgrowth in cortical, sensory, and sympathetic neurons; and the induction of oligodendrocyte differentiation. In order to determine the sites in which IGF-I may play a role in neural development in vivo, the pattern of IGF-I gene expression in the developing rat brain has been analyzed by means of in situ hybridization histochemistry. Transient IGF-I gene expression is seen during the maturation of specific groups of functionally related sensory and cerebellar projection neurons. IGF-I mRNA is abundant within developing cerebellar Purkinje cells and in the major cerebellar relay centers, including the inferior olive, medial vestibular and lateral reticular nuclei of the brainstem, and the deep cerebellar and red nuclei. Similarly, IGF-I mRNA is localized in the synaptic stations of the developing olfactory, auditory, visual, and somatosensory systems. For example, in the auditory system, IGF-I mRNA is abundant in the cochlear nucleus, superior olive, lateral lemniscus, medial geniculate body, and inferior colliculus. In each system, IGF-I gene expression is found predominantly in long-axon projection neurons, appearing during a relatively late stage in their development, at a time of maturation of dendrites and synapse formation. The specific timing and selective localization of neuronal IGF-I gene expression described in this study suggest that IGF-I may have a role in the shaping of systemspecific synaptic connections or myelinization.

Insulin-like growth factor I (IGF-I, somatomedin C) is a member of the insulin gene family best known for its role in the mediation of the effects of growth hormone on longitudinal somatic growth (reviewed by Baxter, 1986; Daughaday and Rotwein, 1989). Under the influence of growth hormone released from the anterior pituitary, the liver synthesizes and secretes IGF-I, which circulates through the bloodstream to reach peripheral target sites. IGF-I is also produced locally in a variety of embryonic and postnatal tissues, suggesting that this peptide

\footnotetext{
Received Feb. 11, 1991; revised June 13, 1991; accepted June 17, 1991

I am grateful to Miles Herkenham and Kent Morest for their neuroanatomical expertise and reviews of the manuscript; to Hal Gainer for his advice, encouragement, and review of the manuscript; to Rick Dreyfuss for photugraphic expertise; and to Charles Roberts and Derek LeRoith for the gift of the IGF-I cDNA clone.

Correspondence should be addressed to C. A. Bondy, NIH, Building 10, Room 10N262, Bethesda, MD 20892.

Copyright (C) 1991 Society for Neuroscience $0270-6474 / 91 / 113442-14 \$ 05.00 / 0$
}

may have distinct tissue-specific autocrine or paracrine roles during the course of normal growth and differentiation and in response to injury (Underwood et a1., 1988; Daughaday and Rotwein, 1989; Bondy et al., 1990; Hansson, 1990). Recent cvidence suggests that IGF-I may have a neurotrophic role. In vitro studies have demonstrated that insulin-like growth factors stimulate mitosis in sympathetic neuroblasts (DiCiccio-Bloom and Black, 1988); promote embryonic neuronal survival and neurite outgrowth in cultured sensory, sympathetic, cortical, and motor neurons (Recio-Pinto et al., 1986; Aizenman and de Vellis, 1987; Caroni and Grandes, 1990); and induce oligodendrocyte differentiation (McMorris and Dubois-Dalq, 1988; Saneto et al., 1988). IGF-I and its receptor are present in human and rat brain (Sara et al., 1982, 1986; Bohannon et al., 1988; Lesniak et al., 1988), where their mRNA levels appear to be developmentally regulated (Rotwein et al., 1988; Werner et al., 1989).

In order to investigate the possible sites of IGF-I action in neural growth and differentiation in vivo, a study of the temporal and neuroanatomical pattern of IGF-I gene expression in the developing rat brain was done using in situ hybridization histochemistry. IGF-I gene expression is scen in a unique array of functionally related central neurons, most strikingly, in sensory and cerebellar relay networks. It presents a highly focal pattern and appears only for a brief window of time in the maturation of the different neural systems. The temporal and topographic pattern of IGF-I gene expression in these systems, analyzed with reference to previously described morphogenetic developments, suggests a role for IGF-I in a relatively late phase of neural differentiation involving dendritic maturation, synaptogenesis, and myelinization.

\section{Materials and Methods}

Timed pregnant Sprague-Dawley rats (Taconic Farms, Germantown, NY) were decapitated following carbon dioxide anesthesia, and fetuses were removed by hysterotomy. Gestational age as calculated taking the day of appearance of the mother's vaginal plug as embryonic day zero (E0). Whole embryos (E14-18) or heads (E20, day of birth) were frozen in dry ice. For postnatal stages, anesthetized male rats were decapitated, and their brains were removed and frozen in dry ice. Sections of $10 \mu \mathrm{m}$ thickness were cut at $-15^{\circ} \mathrm{C}$, thaw mounted onto gelatinized slides, and stored at $-70^{\circ} \mathrm{C}$ until hybridization.

${ }^{35} \mathrm{~S}$-labeled antisense and sense riboprobes were synthesized as previously described (Bondy et al., 1990). The IGF-I subclone used for the synthesis of the cRNA probe contains 376 base pairs corresponding to sequences encoding part of the A-domain, the D-domain, the EbEdomain, and 196 bases of the $3^{\prime}$ untranslated region (Lowe et al., 1988). This probe contains the 52 base insert that is present in IGF-Ib but not IGF-Ia mRNA (the latter being the most abundant species in brain) because of alternative splicing of the transcripts, while all the remaining sequence is common to both species (Lowe et al., 1988). The probes are hydrolyzed into fragments of 100-150 base average length prior to 
use (Bondy et al., 1990). Fragments containing the 52 base insert will not be completely complementary to the IGF-Ia mRNA; however, RNase digestion after hybridization will remove any nonhybridizing bases, leaving approximately $85 \%$ of the labcled probe sequence hybridized to the IGF-Ia mRNA. The fact that a slightly smaller proportion of the cRNA probe sequence will hybridize with the IGF-Ia transcript than with the IGF-Ib transcript does not significantly impair the probe's ability to detect IGF-Ia mRNA in the brain, and, obviously, the probe cannot be used to differentiate these two mRNA species as used in the present protocol.

Prior to hybridization, sections were warmed to $25^{\circ} \mathrm{C}$, fixed in $4 \%$ formaldehyde, and soaked for $10 \mathrm{~min}$ in $0.25 \%$ acetic anhydride, 0.1 $\mathrm{M}$ triethanolamine hydrochloride and $0.9 \% \mathrm{NaCl}$. Tissue was dehydrated through an ethanol series, delipidated in chloroform, rehydrated, and air dried. ${ }^{35} \mathrm{~S}$-labeled probes were added to hybridization buffer $\left(10^{7}\right.$ $\mathrm{dpm} / \mathrm{ml}$ or approximately $50 \mathrm{ng} / \mathrm{ml}$ ) composed of $50 \%$ formamide, 0.3 $\mathrm{M} \mathrm{NaCl}, 20 \mathrm{~mm}$ Tris- $\mathrm{HCl}, \mathrm{pH} 8,5 \mathrm{~mm}$ EDTA, $500 \mu \mathrm{g}$ of $t \mathrm{RNA} / \mathrm{ml}$, $10 \%$ dextran sulfate, $10 \mathrm{~mm}$ dithiothreitol, and $0.02 \%$ each of BSA, Ficoll, and polyvinylpyrollidone. Hybridization buffer was added to slides, which were coversliped and placed in humidified chambers overnight $(14 \mathrm{hr})$ at $55^{\circ} \mathrm{C}$. Slides were washed several times in $4 \times$ salinesodium citrate (SSC) to remove coverslips and hybridization buffer, dehydrated, and immersed in $0.3 \mathrm{M} \mathrm{NaCl}, 50 \%$ formamide, $20 \mathrm{~mm}$ Tris $\mathrm{HCl}$, and $1 \mathrm{~mm}$ EDTA at $60^{\circ} \mathrm{C}$ for $15 \mathrm{~min}$. Sections were then treated with RNase $A(20 \mu \mathrm{g} / \mathrm{ml})$ for $30 \mathrm{~min}$ at room temperature, followed by a $15 \mathrm{~min}$ wash in $0.1 \times \mathrm{SSC}$ at $50^{\circ} \mathrm{C}$. Slides were air dried and apposed to Hyperfilm-beta Max (Amersham) for $4 \mathrm{~d}$ and then dipped in Kodak NTB3 nuclear emulsion, stored with desiccant at $4^{\circ} \mathrm{C}$ for $10 \mathrm{~d}$, developed, and stained with cresyl violet for microscopic evaluation.

At least three embryos were examined at each of the following stages: E14, $-15,-16,-17,-18$, and -20 . As a rule, two were cut in coronal and one or two in sagittal planes. At least two brains were examined at each of the following postnatal ages: postnatal day (D) $-0,-4,-7,-10,-14$, $-21,-28$, and -60 . Sections for a particular brain region from the different age groups were prepared, hybridized, washed, exposed, and developed together to facilitate comparison of signal intensity across the different developmental stages. Figures containing autoradiographs and micrographs comparing IGF-I gene expression at different ages represent data acquired in a single experiment. Controls in the form of parallel tissue sections hybridized to a "sense" probe, or pretreated with RNase A, were hybridized, washed, and exposed in the same experiments. The background, or nonspecific, signal from these sections was very minimal. Hybridization with a cRNA for a related sequence, that is, IGF-II, yielded very different results, with this mRNA not detected in neurons at any stage of development (Bondy et al., 1990; C. A. Bondy, unpublished observations).

\section{Results}

The development of the rat cerebellar cortex takes place in the first few postnatal weeks, and during this period, there is intense IGF-I gene expression in the principal cerebellar cortical neurons, the Purkinje cells. Large Purkinje cell bodies are recognizable in the cerebellar anlage as early as E18, but Purkinje IGF-I mRNA is not detected until the day of birth and is maximal between D4 and D10 (Fig. 1). By D28, when the development of the cerebellar cortex is largely complete, Purkinje cell IGF-I mRNA detection is significantly diminished compared with D10 (Fig. 1), and by D60 it is just above background levels (see Fig. 9A-C). IGF-I mRNA is not detected in cerebellar interneurons at any stage of development. A few IGF-I mRNAcontaining cells are transiently detected from D10 to D14 in the white matter of cerebellar folia (Fig. 1).

IGF-I gene expression is also very marked during the maturation of the components of the cerebellar relay system, including the inferior olivary, deep cerebellar, medial vestibular, lateral reticular, pontine, and red nuclei (Figs. 2-4; Table 1). Each of these centers is a part of the circuitry in which the cerebellar cortex monitors and coordinates motor activity and is, directly or indirectly, synaptically linked to the Purkinje cell. Microscopic examination of nuclear emulsion-coated sections shows that, in these nuclei as in the cerebellar cortex, silver grains representing IGF-I mRNA are concentrated over large projection neurons and not over local circuit neurons (see Fig. $4 G-I)$.

IGF-I gene expression is very intense in the maturing trigeminal somatosensory relay system. The highest levels of somatosensory IGF-I mRNA are found during the first three postnatal wecks in thalamic nuclei: the ventrobasal complex and the anterior pretectal, gelatinosa, and intralaminar nuclei (Figs. 3, 4; Table 1). IGF-I mRNA is also transiently localized in projection neurons of the principal sensory trigeminal nucleus (Fig. 2) and trigeminal ganglion neurons (Figs. 3, 4). We have previously shown that early in rat embryonic development (E12-15), IGF-I mRNA is focally localized in the peripheral target zones of the trigeminal nerve (Bondy et al., 1990; Bondy and Chin, 1991). The spinal somatosensory system was not extensively examined in the present study; however, IGF-I mRNA-containing cells are present in the dorsal column nuclei in D0, D7, and D14 brains (Fig. $2 A$ ), although at a lower density than found in the spinal trigeminal nuclei. The spinal cord, which was not examined in this study, has been reported to contain abundant IGF-I mRNA (Rotwein et al., 1988).

IGF-I mRNA is highly abundant in mitral and tufted cells, the projection neurons of the olfactory bulb. Prenatally, these neurons form cell-dense concentric layers around the olfactory bulb, and both cell layers contain abundant IGF-I mRNA (Fig. $5 A, B)$. Postnatally, mitral and especially tufted cells are dispersed by the increase in olfactory bulb diameter and the accumulation of neuropil in the plexiform and glomerular layers, and there is a corresponding dispersal of their IGF-I mRNA signal (Fig. 5C,D); however individual mitral and tufted cells contain abundant IGF-I mRNA at the latest stage examined (D60; Table 1). These olfactory system neurons project to the piriform cortex, where IGF-I mRNA is also found in large projection neurons, the pyramidal cells (see Fig. $8 C$, Table 1). The onset of IGF-I gene expression in the olfactory cortex occurs between D4 and D7 and continues unabated throughout adult life, as in the olfactory bulb.

There is a moderate level of IGF-I gene expression throughout the stations of the visual projection system. The IGF-I signal over the developing neural retina is confined to the postmitotic, postmigratory ganglion cell layer (Fig. $5 A, B$ ). IGF-I mRNA is present in major retinal projection centers, the lateral geniculate nuclei (Fig. 6) and the superior colliculus (Figs. 6, 7B). The lateral dorsal and anterior pretectal nuclei of the thalamus also contain IGF-I mRNA (Fig. 6, Table 1). The anterior pretectal nucleus actually has both somatosensory and visual components in the rat (Arango and Scalia, 1984). It is interesting to note that the ventral part of this nucleus, which receives the somatosensory input, shows a denser IGF-I mRNA signal than the dorsal portion, which receives the visual projection (Fig. 6). IGF-I $m R N A$ is abundant in the developing auditory and vestibular relay systems, including the cochlear (dorsal and ventral) and medial and superior vestibular nuclei from E20 through D14 (Fig. 7A, Table 1). The most caudal portions of the medial vestibular and the spinal vestibular nuclei contain little IGF-I mRNA, however (Fig. 2A). In the case of the cochlear nuclei, individual types of IGF-I mRNA-containing projection neurons were identified; these included globular, fusiform, and giant cells. IGF-I mRNA is first detected in the lateral superior olive and rostral periolivary area on E20, increases in abundance through D14 (Fig. 7B), and subsequently decreases, but is readily 


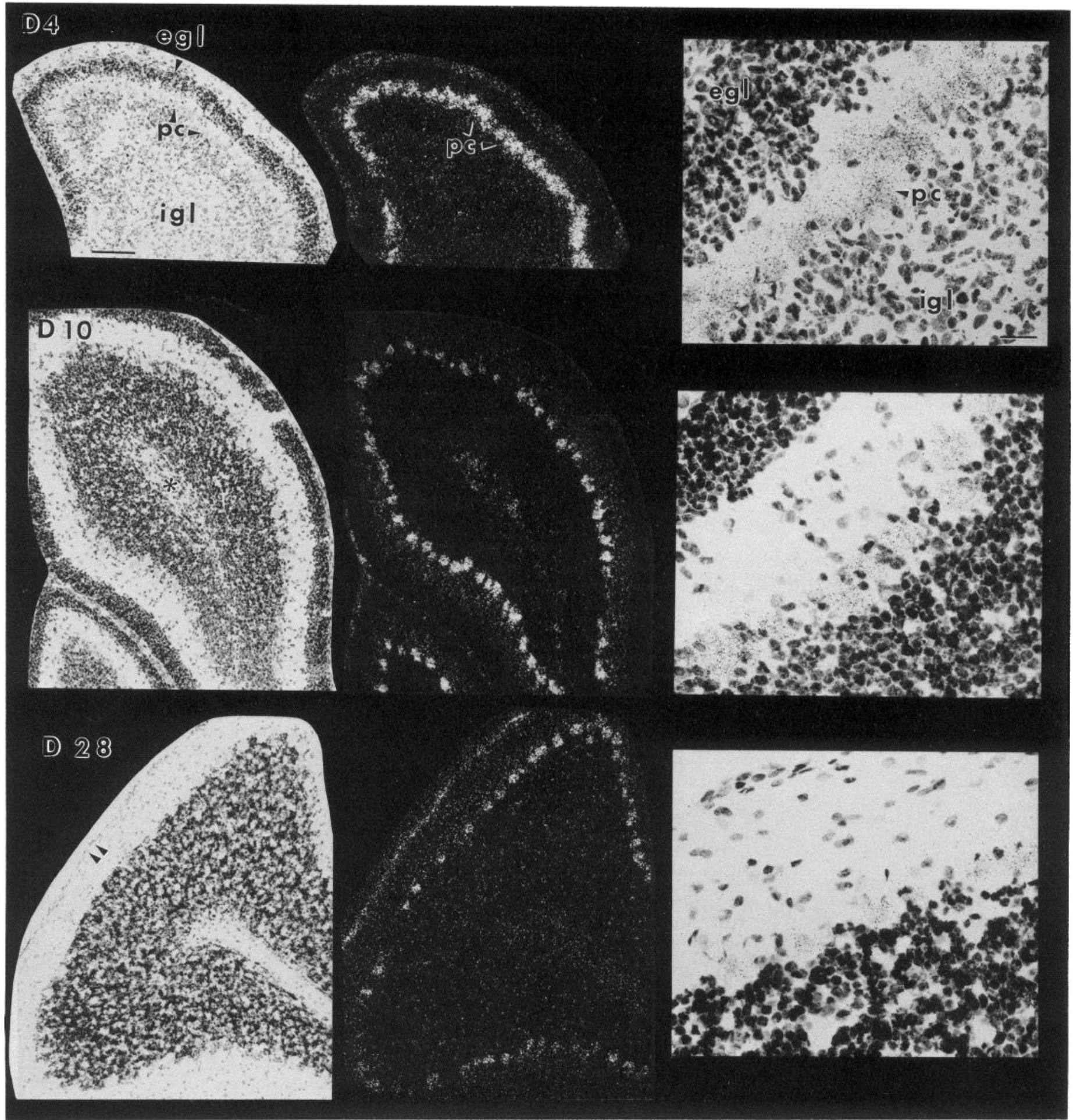

Figure 1. IGF-I mRNA localization in Purkinje cells of the developing cerebellar cortex shown by in situ hybridization histochemistry. Top, D4; middle, D10; bottom, D28. On the left of each panel are paired bright- and dark-field micrographs of cerebellar folia from each developmental stage. Silver grains representing hybridized IGF-I mRNA appear white in the dark-field (scale bar, $100 \mu \mathrm{m}$ ). On the far right of each panel are highpower bright-field micrographs focusing on the Purkinje cell layer, where the silver grains are seen as black dots (scale bar, $12 \mu \mathrm{m}$ ). On D4, the external granule cell layer $(e g l)$ is 5-10 cells deep, and the molecular layer separating it from the Purkinje cell layer $(p c)$ is rudimentary. Purkinje cells are packed closely together at this stage; however, the pale outline of individual cells may be discerned behind each cluster of silver grains. By D10, the internal granular layer ( $i g l)$ has grown considerably due to the migration of cells from the external granule layer, and the Purkinje cell layer is spread thinner, with individual cells easily identified. The hybridization signal over individual Purkinje cells of D10 appears roughly equal to that of D4. The molecular layer has expanded as a result of the accumulation of fibers laid down by the migrating granule cells and the proliferation of Purkinje dendrites. By D28, the external granule layer has largely disappeared, almost all granule cells are now in the inner layer, and the level of IGF-I mRNA detected in each Purkinje cell, as measured by the number of silver grains located over each cell, has diminished appreciably. IGF-I mRNA is transiently detected in cells of the cerebellar medulla (asterisk in the D10 low-power bright-field photomicrograph) and leptomeninges (double arrowheads). 
Table 1. Timing of peak IGF-I gene expression in specific neuroanatomical loci of the developing rat CNS

\begin{tabular}{|c|c|c|}
\hline System & Component & Period $^{a}$ \\
\hline \multirow[t]{5}{*}{ Cerebellar } & Purkinje cell & D4-D28 \\
\hline & Inferior olive & E20-D21 \\
\hline & Deep cerebellar nuclei & E20-D21 \\
\hline & Red nucleus & D4-D28 \\
\hline & Ventrolateral nucleus & D4-D21 \\
\hline \multirow[t]{6}{*}{ Somatosensory } & Spinal trigeminal nucleus & E20-D21 \\
\hline & Ventrobasilar nucleus & D4-D21 \\
\hline & Gelatinosa nucleus & $\mathrm{E} 20-\mathrm{D} 14$ \\
\hline & Intralaminar nucleus & E18- \\
\hline & Anterior pretectal nucleus & E16-D28 \\
\hline & Dorsal column nucleus ${ }^{b}$ & DO- \\
\hline \multirow[t]{3}{*}{ Olfactory } & Mitral cell & E16- \\
\hline & Tufted cell & E18- \\
\hline & Piriform cortex ${ }^{c}$ & D7- \\
\hline \multirow[t]{5}{*}{ Visual } & Retinal ganglion cells & E20-D10 \\
\hline & Superior colliculus & $\mathrm{D} 0-$ \\
\hline & Lateral geniculate nucleus & D7-D28 \\
\hline & Lateral posterior nucleus & D7-D28 \\
\hline & Anterior pretectal nucleus & E16-D28 \\
\hline \multirow[t]{9}{*}{ Auditory-vestibular } & Medial vestibular nucleus & E20-D21 \\
\hline & Superior vestibular nucleus & E20-D21 \\
\hline & Dorsal cochlcar nuclcus & E20-D14 \\
\hline & Ventral cochlear nucleus & D0-D14 \\
\hline & Superior olive & E20- \\
\hline & Lateral lemniscal nucleus & E20-D28 \\
\hline & Medial geniculate nucleus & D4-D21 \\
\hline & Inferior colliculus & D0-D28 \\
\hline & Interstitial nucleus & E20-D14 \\
\hline \multirow[t]{13}{*}{ Other } & Nucleus basalis & E20-D14 \\
\hline & Diagonal band nucleus & E20-D21 \\
\hline & Lateral septal nucleus & E20-D21 \\
\hline & Medial habenula & E20-D14 \\
\hline & Ventral tegmental nucleus & E20-D14 \\
\hline & Dorsal tegmental nucleus & E20-D14 \\
\hline & Entopeduncular nucleus & D0-D21 \\
\hline & Parafascicular nucleus & E16-D7 \\
\hline & Retroflexus nucleus & E16-D7 \\
\hline & Parabrachial nucleus & E20-D7 \\
\hline & Substantia nigra, pars lateralis & D0-D21 \\
\hline & Hippocampus $^{d}$ & E20-D28 \\
\hline & Neocortex ${ }^{e}$ & D0-D28 \\
\hline
\end{tabular}

a The times encompass the day on which the structure was first found to contain IGF-I mRNA to the time when levels have diminished to near background, although faint shadows representing a low level of IGF-I mRNA continue to be seen indefinitely in most areas-see, for example, the ventrobasilar complex in Figure 3, D21. Where the time is left open, for example, for components of the olfactory system, IGF-I mRNA is readily detectable at the latest stage examined (D60).

- The dorsal column nuclei were examined only in sections from D0 to D14 and were positive at each time point.

- IGF-I mRNA is concentrated in pyramidal cells.

${ }^{d}$ IGF-I mRNA is contained in nonpyramidal cells localized in the strata oriens and radiatum.

- IGF-I mRNA is localized in large, pale cells that are found in a nonlaminar distribution.

detectable at the latest stage examined (D60; Table 1). The nuclei of the lateral lemnicus, the inferior colliculus (Fig. 7), and the interstitial nucleus of Cajal (Fig. 6) also contain IGF-I mRNA during the course of development (Table 1).

IGF-I mRNA is localized in the basal nucleus of Meynert, the horizontal and vertical limbs of the diagonal band of Broca, and in the dorsal lateral septal nucleus (Fig. 8, Table 1). IGF-I mRNA is first seen in these areas on E20 and has largely disappeared from them by D21. IGF-I mRNA is concentrated in nonpyramidal and nongranular cells of the hippocampal formation (Fig. 9D-F) and shows a distinctly different developmental pattern of expression in these cells, the analysis of which 


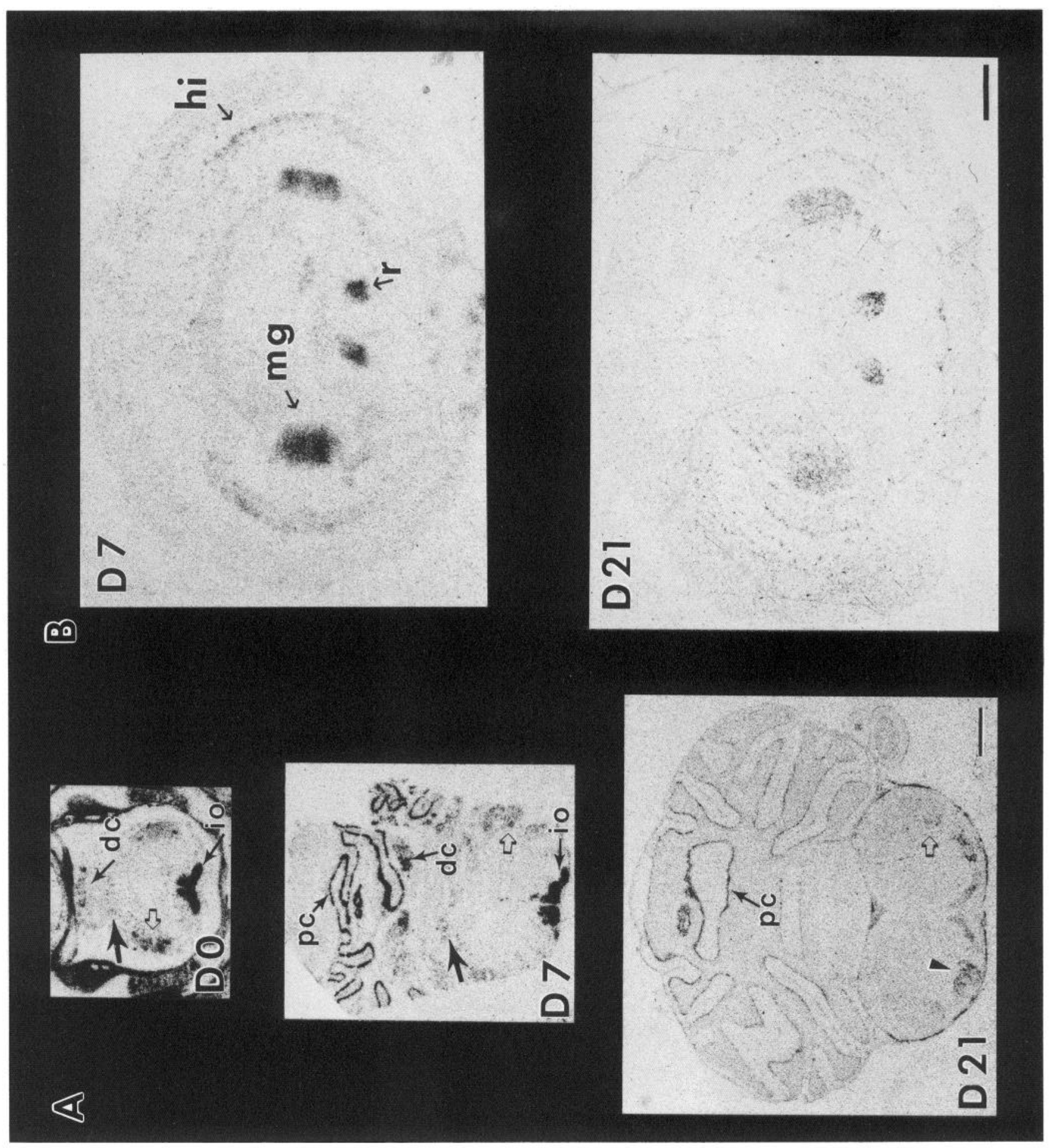


is the subject of a manuscript in preparation. Other CNS structures containing IGF-I mRNA during development are listed in Table 1 .

\section{Discussion}

This study has shown that IGF-I mRNA is distributed in a unique array of large, functionally related projection neurons in the developing rat CNS. These neurons, for the most part, belong to sensory and cerebellar relay networks. IGF-I gene expression in these systems is cphemeral, appearing only for a brief period of time during the maturation of each component (except for apparently lifelong expression in the olfactory system; see below).

A recent in situ hybridization study employing a human cDNA probe reported that IGF-I mRNA was concentrated in the celldense regions of the adult rat brain, that is, the granule cell layers of olfactory bulb, cerebellum, and dentate gyrus and the pyramidal cell layer of Ammon's horn (Werther et al., 1990). These findings illustrate a commonly seen nonspecific binding pattern that has been particularly evident with the use of cDNA probes (Higgins and Wilson, 1987). Double-stranded cDNA probes show a very high degree of self-annealing that competes effectively against the formation of intrinsically less stable RNA: DNA hybrids (Cox et al., 1984). I his problem is likely to be even more serious when the cDNA probe is only $72 \%$ homologous to the target mRNA (Shimatsu and Rotwcin, 1987), as in the Werther et al. (1990) study. A number of other factors in the previous study would be expected to contribute to a high degree of nonspecific signal, including the absence of blocking of tissue electrostatic charges, a prolonged (4 d) hybridization period, and low stringency washes (Cox et al., 1984; Singer et al., 1987). The use of a single-stranded, homologous IGF-I cRNA probe in the present in situ hybridization study provides very. significant advantages over the above-described protocol. Single-stranded cRNA probes have been shown to have an approximately eightfold higher sensitivity than comparable cDNA probes in detection of target mRNA in situ (Cox et al., 1984), and their use allows for a major reduction of nonspecific signal through the RNase digestion of nonhybridized probe and the application of high-stringency wash conditions. Using these techniques and a specific rat cRNA probe for IGF-I, the present study finds little hybridization over the granule cells of the olfactory bulb, cerebellum, or hippocampus at any stage of development. Other studies employing a variety of oligonucleotide probes complementary to the rat IGF-I mRNA have detected IGF-I in mitral and tufted but not in granule cell layers of adult (Bondy, unpublished observations) and fetal rat olfactory bulb (Ayer-le Lievre, 1991). Immunocytochemical evidence places
IGF-I immunoreactivity in the Purkinje cclls, but not in the granule cells of the adult cerebellum (Andersson et al., 1988; see discussion below). It thus appears very likely that the signal detected over the cell-dense regions of the adult rat brain by Werther et al. (1990) may be due to nonspecific tissue retention or cross-hybridization of the heterologous cDNA probe.

This study has described a transient high level of IGF-I gene expression in specific groups of functionally related sensory and cerebellar projection neurons during a relatively late phase in their development. In each sensory and cerebellar center where detailed morphogenetic information is available for comparison, IGF-I gene expression is found to be time-locked to periods of dendritic maturation and synaptogenesis. The cerebellar cortex is the brain region where the process of neuronal maturation has been described in the most comprehensive and elegant detail. Purkinje cells, the projection neurons of the cerebellar cortex, have been born, migrated, and settled in the ccrebcllar plate by E17 (Addison, 1911). There they remain, apparently without further development until the time of birth, when a wave of germinal cells arising from the rhombic lip migrates into the cerebellar plate. These cells form a transient germinal zone in the external granular layer of the cerebellum (Addison, 1911; Ramon y Cajal, 1911; Altman, 1972). It is during this period that Purkinje cells mature and form extraordinarily prolific dendritic arbors through which each Purkinje neuron receives hundreds of thousands of synapses from granule cell axons and from climbing fiber axons arising from the inferior olive. During the peak of Purkinje dendritogenesis and synapse formation (D421), Purkinje cells maintain a high level of IGF-I gene expression (Fig. 1). There is little published information on the maturation of cerebellar relay centers in the rat except in the case of the inferior olive, where synaptic maturation reportedly occurs from D0 to D15 (Bourrat et al., 1989), in parallel with peak IGF-I gene expression.

IGF-I mRNA is first detected in the projection neurons of the olfactory bulb on E16-just about the time when the first olfactory bulb synapses are detected (Gesteland et al., 1982). IGF-I mRNA is not detected in the piriform cortex until after D4, while synapse formation begins prenatally in this region; however, there is extensive neuropil growth and maturation after this time as well (Westrum, 1975). The lifelong persistance of IGF-I genc cxpression in the olfactory system may be related to the fact that it is characterized by a lifelong process of new synapse formation due to the continual turnover of the primary olfactory neurons (Graziadei and Monti-Graziadei, 1978). Other factors associated with neurite outgrowth such as GAP-43 are also persistently expressed in the olfactory system (De la Monde et al., 1989).

Figure 2. IGF-I mRNA localization in developing cerebellar relay stations shown by film autoradiography. $A$, Coronal sections through the medulla and cerebellum from $D O$ to $D 21$. The top section $(D O)$ is through the entire head of a neonatal rat. IGF-I mRNA is present in the connective tissue and membranous bone surrounding the brain stem. A small tissue fold lies over the top of the section, obscuring the developing cerebellar cortex, which is rudimentary (and IGF-I mRNA negative) at this stage. The deep cerebellar nuclei $(d c)$ have formed by $D 0$, however, and contain IGF-I mRNA, which increases in abundance through $D 7$ and then declines. The inferior olivary nuclei (io) are intensely positive for IGF-I mRNA at the time of birth and through $D 7$, after which time their signal diminishes. The principal trigeminal (sensory) nucleus, indicated by open arrows, shows a similar pattern. The lateral reticular nuclei (arrowheads) are moderately positive from $D 7$ (not easily visible in this section) through $D 21$, after which they become negative. IGF-I mRNA-containing cells are also localized in the cuneate (indicated by solid arrows in DO and D7) and gracile nuclei, although these centers are not as densely labeled as the trigeminal nuclei. $B$, Autoradiographs of anatomically matched coronal sections through the mesencephalon. IGF-I mRNA is extremely abundant in the red nuclei ( $r$ ), major cerebellar relay nuclei, and also both the dorsal and ventral divisions of the medial geniculate bodies ( $m g$; see also Fig. 6), components of the auditory relay system, from the first postnatal week until $D 21$. All the sections shown in $A$ and $B$ were hybridized in the same experiment and exposed for $4 \mathrm{~d}$ on a single piece of film. $p c$, Purkinje cell layer; $h i$, hippocampal formation; $m g$, medial geniculate body. Scale bars, $1 \mathrm{~mm}$. 
Figure 3. Ephemeral IGF-I mRNA localization in developing somatosensory relay centers. Film autoradiographs of anatomically matched sections through the anterior diencephalon show a dramatic appearance and disappearance of IGF-I mRNA in the ventrobasal nuclei $(v b)$ during the first 3 weeks after birth. IGF-I mRNA is present in the gelatinosa nuclei $(g$; also a part of the somatosensory system) at birth and has largely disappeared by D14. The intralaminar nuclear complex (il) shows a prolonged course of IGF-I gene expression, which is still quite distinct well into adulthood. The D14 section is a little more rostral than the others in the series, and a portion of the ventrolateral thalamic nucleus $(v l)$ is seen. Some IGF-I mRNA-containing ganglion cells are found in the lateral (mandibular) portion of the trigeminal nerve (5), which is seen running along the ventral surface of the brain. A more diffuse IGF-I mRNA signal arises from trigeminal nerve Schwann cells and the perineurium. $m h$, Medial habenula; $h i$, hippocampus; $e p$, entopeduncular nucleus. Scale bar, $1 \mathrm{~mm}$.
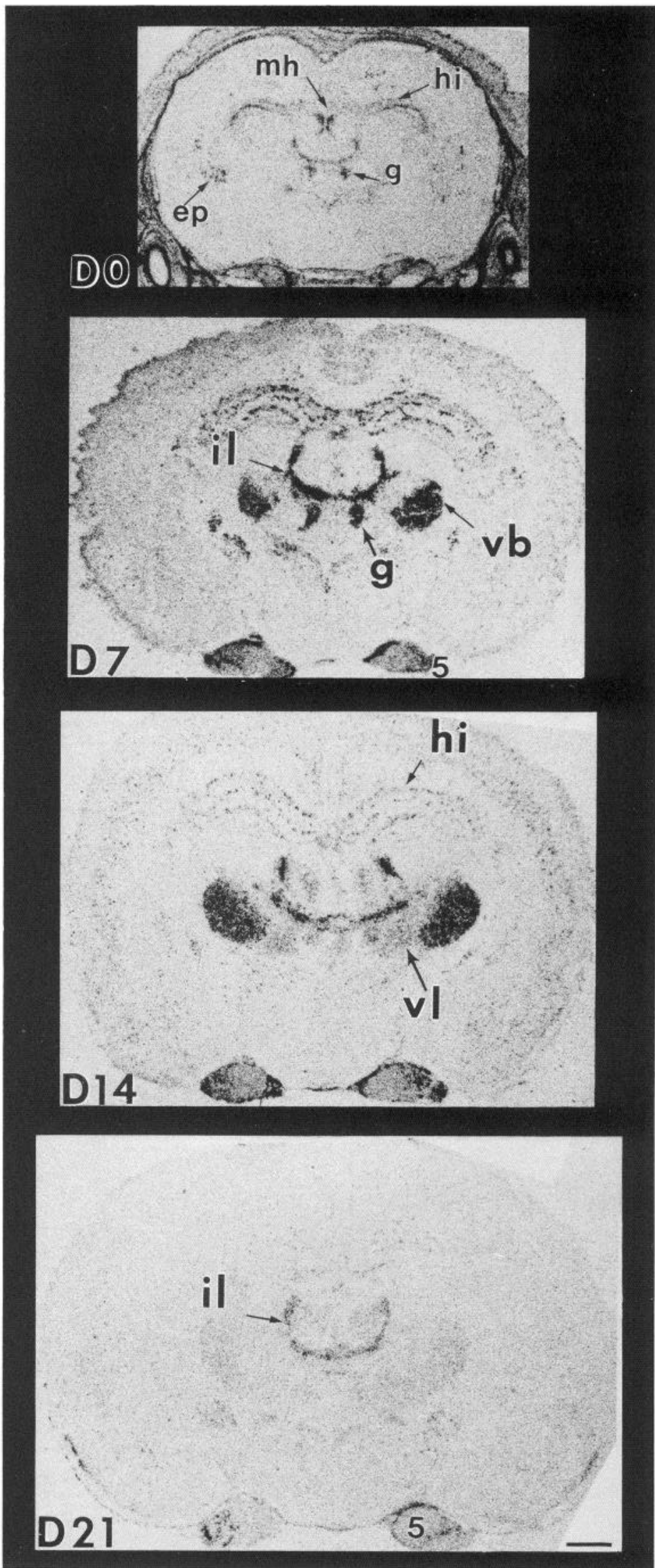

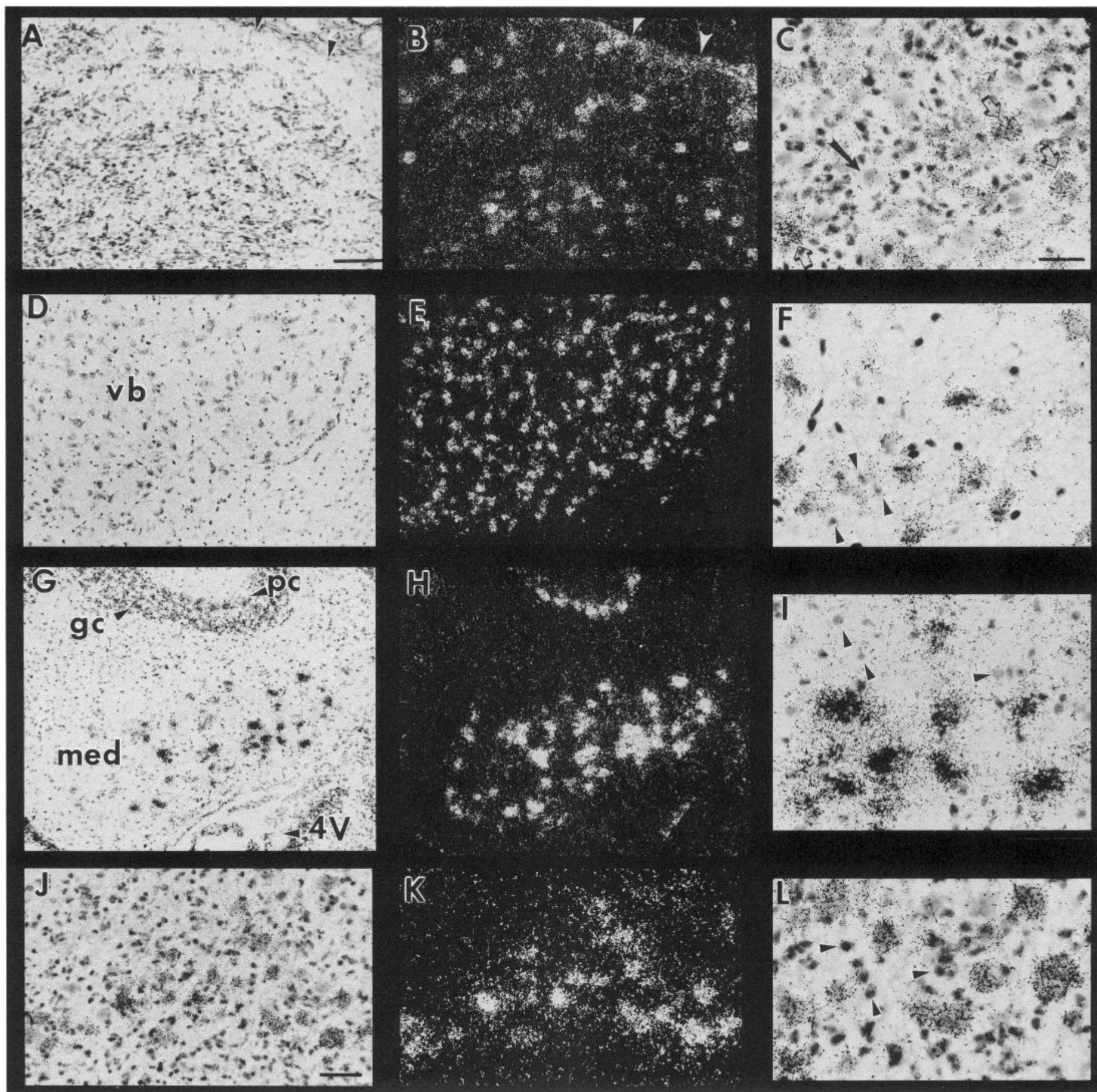

Figure 4. IGF-I mRNA in somatosensory and cerebellar projection neurons. $A$ and $B$ show paired, low-power bright- and dark-fields, respectively, through the trigeminal ganglion on E20. $C$ shows a higher-power magnification of a portion of this ganglion. Primary sensory neurons have large perikarya with pale cytoplasm and large, pale nuclei. Some of these cells contain abundant IGF-I mRNA (open arrows), while others do not (solid arrow). Fibroblasts in the perineurium also express IGF-I mRNA (arrowheads in $A$ and $B$ ). $D$ and $E$ show paired bright- and dark-field micrographs, and $F$, a high-power micrograph of the ventrobasilar nucleus in a coronal section from a D10 brain. $G$ and $H$ are paired bright- and dark-field views of a sagittal section through a D10 rat cerebellum. $I$ is a high-power micrograph of the same section shown in $G$ and $H$ showing the large IGF-I mRNA-positive cells in the medial cerebellar nucleus. $J$ and $K$ show bright- and dark-field micrographs of a sagittal section through the caudal region of a D10 red nucleus, and $L$ is a high-power micrograph of the same section. Arrowheads in $F, I$, and $L$ point out interneurons. $g c$, Granule cells of the internal granule cell layer of the cerebellar cortex (the external granule cell layer is not visible in this micrograph); med, medial nucleus of the cerebellum; $p c$, Purkinje cell layer; $4 V$, fourth ventricle; $v b$, ventrobasilar nucleus of the thalamus. Scale bars: $A, D$, and $G$, $100 \mu$ m; $J$ and $K, 50 \mu \mathrm{m} ; C, F, I, L, 20 \mu \mathrm{m}$. 
Figure 5. IGF-I mRNA in the olfactory bulb on E20 and D20. $A$ is a hematoxylin-eosin-stained section through the forehead of an E20 rat embryo showing, most prominently, the developing olfactory bulb $(o b)$ and eye. $B$, shows a film autoradiograph taken from the section shown in $A$. The open arrow points to the nascent glomerular layer of the olfactory bulb, which is composed largely of tufted neurons and olfactory nerve fibers at this stage. The solid arrowhead points to the mitral cell layer of the olfactory bulb. IGF-I mRNA is very abundant in the ocular iris $(i)$, and moderate levels are seen in the ganglion cell layer (innermost cell layer) of the neural retina $(r)$, and in the retinal pigment epithelium (outermost cell layer of the retina). $C$ shows a Nissl stain and $D$ the film autoradiograph of a coronal section through a D20 olfactory bulb. IGF-I mRNA-containing tufted cells are now distributed in the outer part of the external plexiform layer $(e p l)$ and among the glomeruli, resulting in a dispersal of the olfactory bulb's outer ring of IGF-I mRNA hybridization signal among these layers. $g c$, Granule cell layer; $g l$, glomerular layer; $m c$, mitral cell layer; onl, olfactory nerve layer. Scale bar, $1 \mathrm{~mm}$.

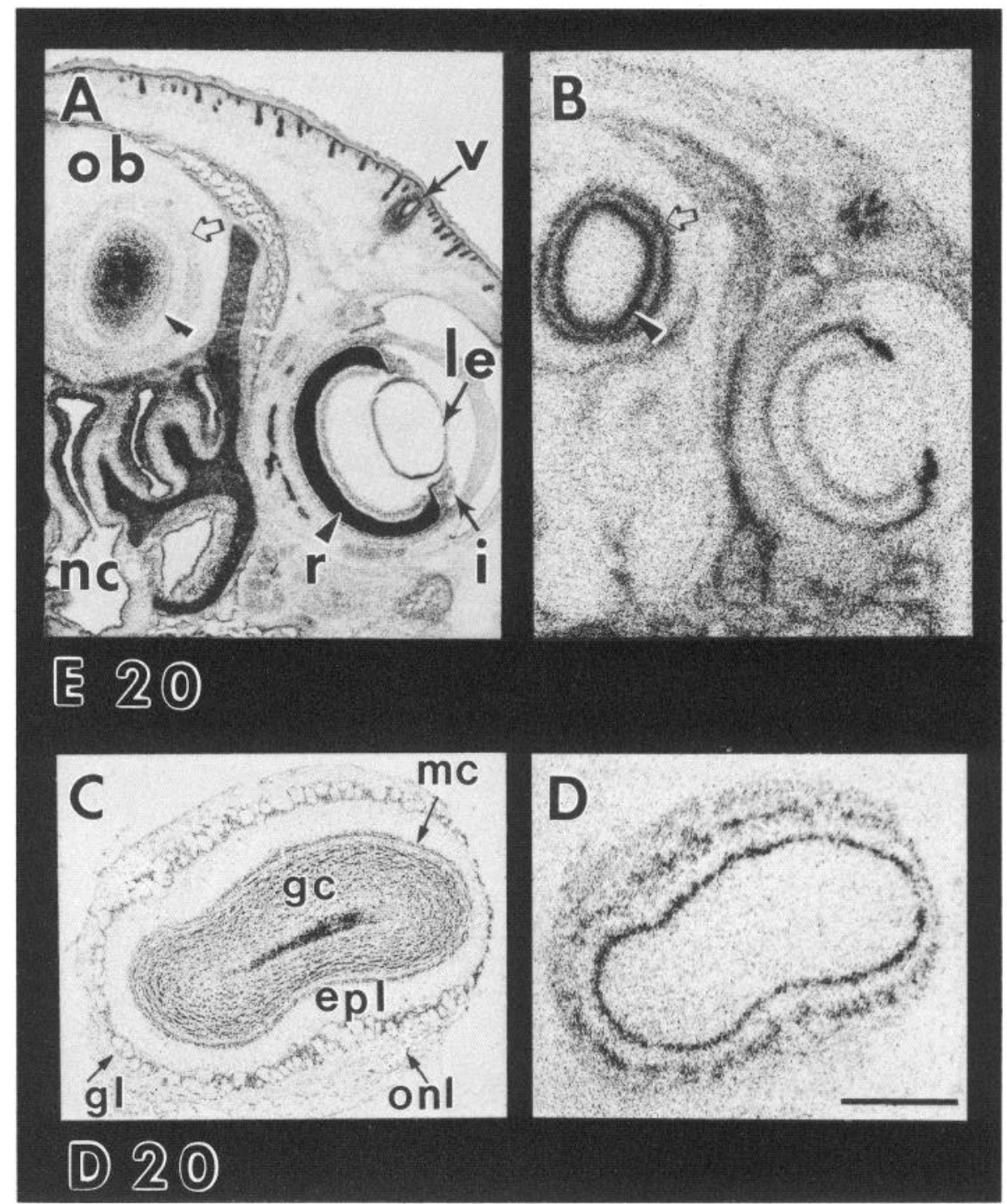

IGF-I mRNA is highly abundant in somatosensory thalamic nuclei during the period in which specialized dendritic appendages are formed and shaped into the complex intrinsic synaptic circuitry that is characteristic of the somatosensory thalamus (Scheibel and Scheibel, 1978). Morphological maturation and IGF-I gene expression (Fig. 3) are seen somewhat earlier in the central (intralaminar and gelatinosa) thalamic nuclei than in the ventrobasal complex. Thus, similar to the pattern seen in the cerebellar system, IGF-I gene expression in the somatosensory thalamus tracks a stage of neuropil maturation and synaptogenesis. Further studies will be necessary to determine if IGF-I gene expression in the spinal cord and dorsal column nuclei also parallels the state of synaptic maturation in these areas. A detailed and site-specific analysis of IGF-I's pattern of gene expression in the developing visual and auditory/vestibular systems is beyond the scope of the present study; however, it can be stated that there is a transient increased level of IGF-I gene expression in many of the components of the visual and auditory/vestibular projection systems during the course of their postnatal development.
Whereas dendritic growth and synapse formation are global aspects of brain development, IGF-I gene expression is most strikingly concentrated in the large projection neurons belonging to ascending cerebellar and sensory pathways. The primary distinguishing feature of these neurons is their participation in highly elaborate synaptic arrangements forming the basis for the complex information processing characteristic of these systems. Since this idiomatic, or system-specific, synaptic architecture is being laid down during the time of peak IGF-I gene expression, it is possible that IGF-I plays a role in this specialized synapse formation. The fact that IGF-I has neurite-stimulating activity in vitro (Recio-Pinto et al., 1986; Aizenman and de Vellis, 1987; Caroni and Grandes, 1990) adds weight to this hypothesis. A number of membrane-associated proteins that are expressed during the course of neural development and have a system- or circuit-specific distribution have been described in recent years (Hockfield and McKay, 1983; Levitt, 1984; Bastiani et al., 1987). It appears that these molecules may play a role in the formation of specific projections during development. Such a role is not likely for IGF-I, however, because it is synthesized during a 


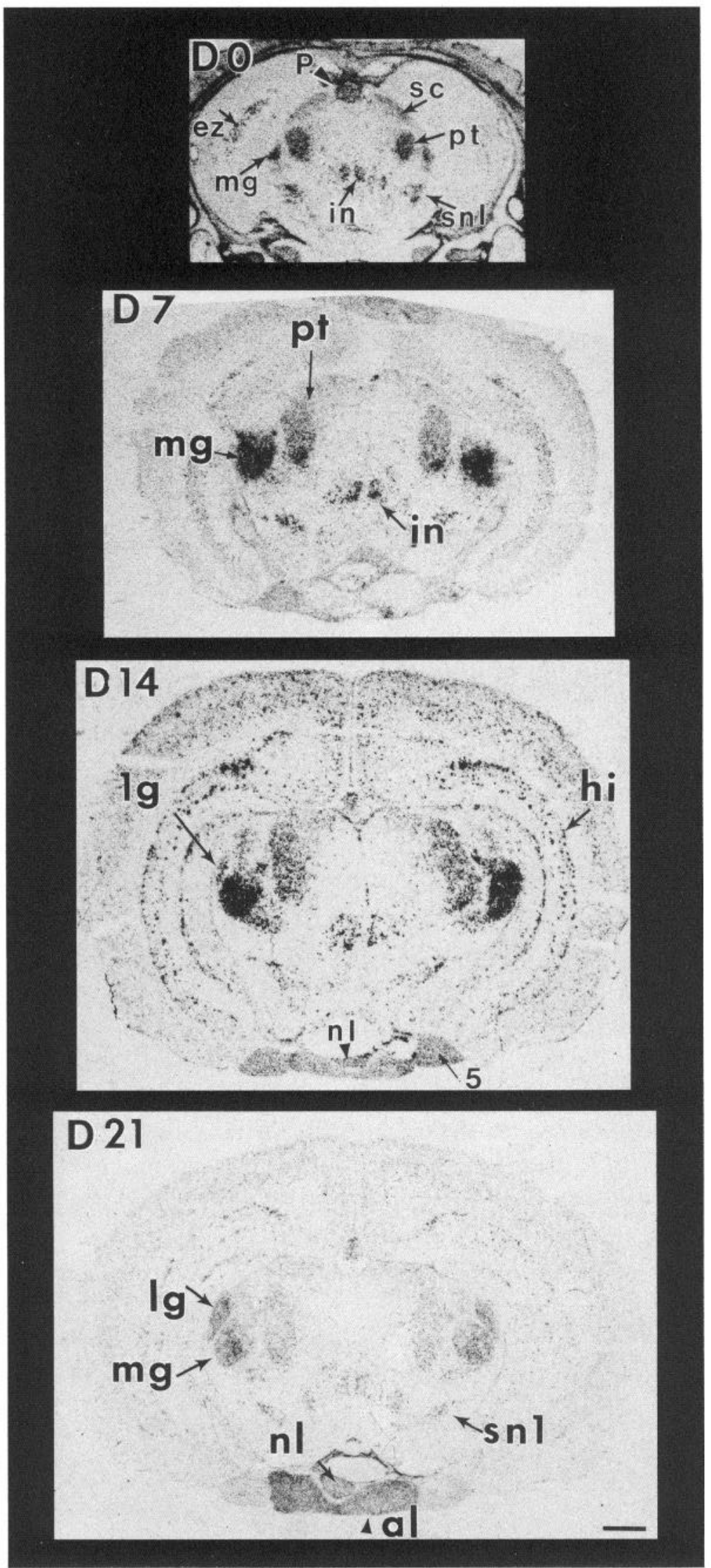

Figure 6. IGF-I gene expression in developing visual and auditory/vestibular sensory relay systems. The anterior pretectal nuclei $(p t)$ contain abundant IGF-I mRNA at the time of birth, which gradually fades during maturation. The dorsal lateral geniculate nucleus $(l g)$ contains IGF-I mRNA from $D 7$ to $D 28$. This nucleus is not present, however, in the $D 7$ section shown here; its caudal portion is seen in the D14 and D21 sections, because the nucleus extends caudally in the course of postnatal development. The medial geniculate nuclei $(\mathrm{mg})$ show increasing IGF-I gene expression from $D 0$ to $D 14$, after which there is a gradual decline. The interstitial nucleus of Cajal (in) contains abundant IGF-I mRNA at birth, which declines steadily thereafter. al, Anterior lobe of the pituitary; $e z$, ependymal zone; $n l$, neural lobe of the pituitary; $p$, pineal body; $s c$, superior colliculus; $s n l$, pars lateralis of the substantia nigra; 5 , trigeminal nucleus. Scale bar, $1 \mathrm{~mm}$. 
Figure 7. IGF-I mRNA localization in auditory/vestibular relay systems 2 weeks after birth in the rat. Film autoradiographs of coronal sections through rostral medulla/cerebellum $(A)$ and caudal mesencephalon $(B)$. The section shown in $B$ has the ventral surface slightly more caudal and the dorsal surface more rostral than the section shown in the Paxinos atlas (plates 50,51). ic Inferior colliculus; $l l$, nuclei of the lateral lemniscus; $m v$, medial vestibular nucleus; $p c$, Purkinje cell layer; $r p o$, rostral periolivary area; $s c$, superior colliculus; $v c$, ventral cochlear nucleus; $v t$, ventral tegmental nucleus. Scale bar, 1 $\mathrm{mm}$.

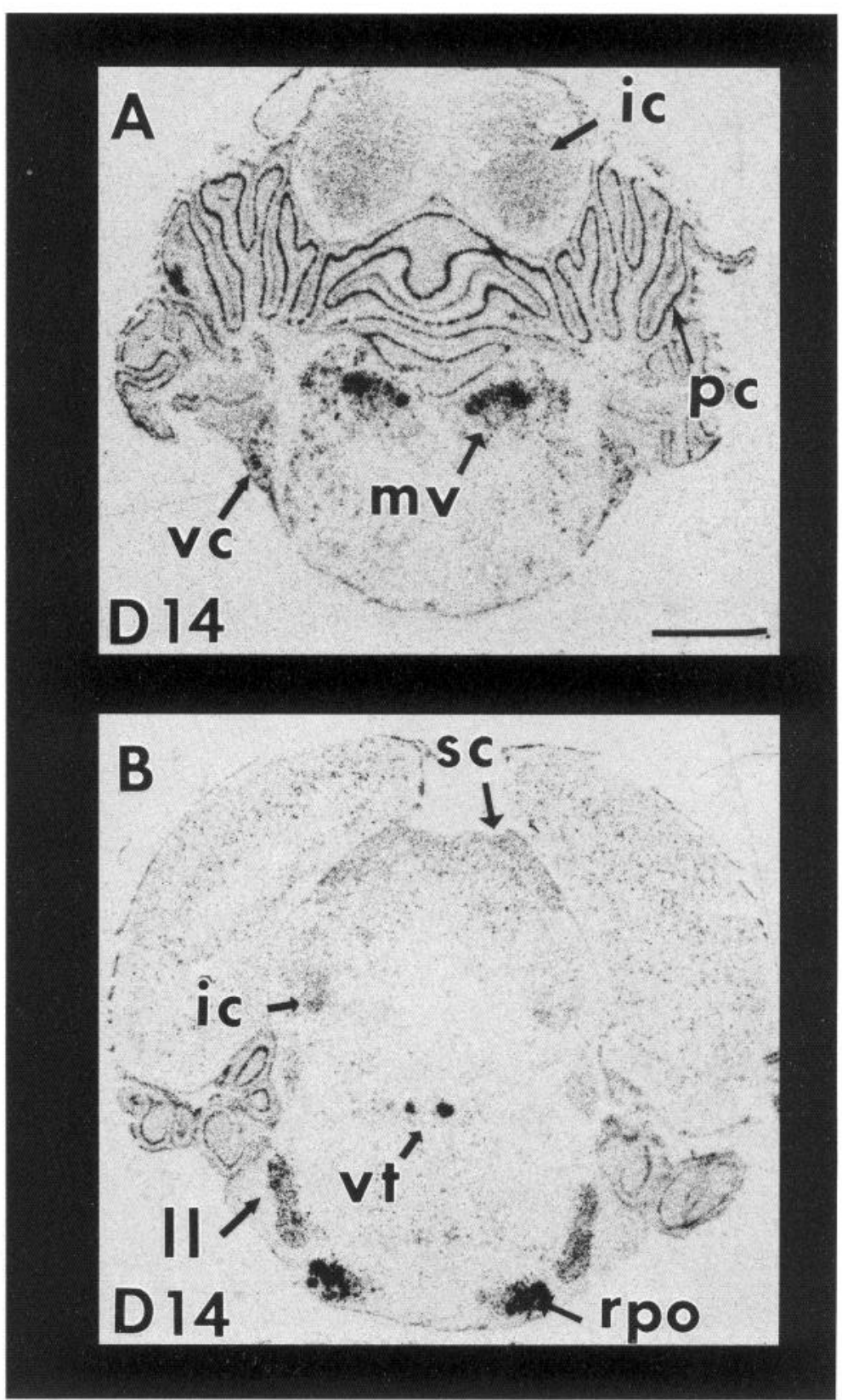

later phase of development, after the basic circuit connectivity has been established, during a time of synaptic maturation. For example, the initial climbing fiber input from the inferior olives has already been established before the appearance of IGF-I gene expression in the target Purkinje cells.

Another possibility that is compatible with the late timing of IGF-I gene expression [and IGF-I's trophic effects on oligodendrocytes in vitro (McMorris and Dubois-Dalq, 1988; Saneto et al., 1988)] is that IGF-I has a role in promotion of myelinization in these systems. Since myelinization follows closely upon and sometimes overlaps the process of synaptogenesis, the timing of IGF-I gene expression does not clearly distinguish between the two possibilities. If IGF-I is primarily involved in promoting myelinization, however, it is unclear why it is primarily cerebellar and sensory and not other central myelinated systems that show such intense IGF-I gene expression during this phase of development.

The potential site of action of neuronal IGF-I is a matter of speculation at present, because little is known of the manner of neuronal IGF-I processing, packaging, or secretion. A recent immunocytochemical study of IGF-I peptide localization in the developing cerebellar cortex (Andersson et al., 1988) found that IGF-I immunoreactivity is present in Purkinje cells from shortly after birth to D28. IGF-I immunostaining is particularly intense in the nascent molecular layer. Granule cells of the germinal zone in the external granular layer are negative, but differenti- 


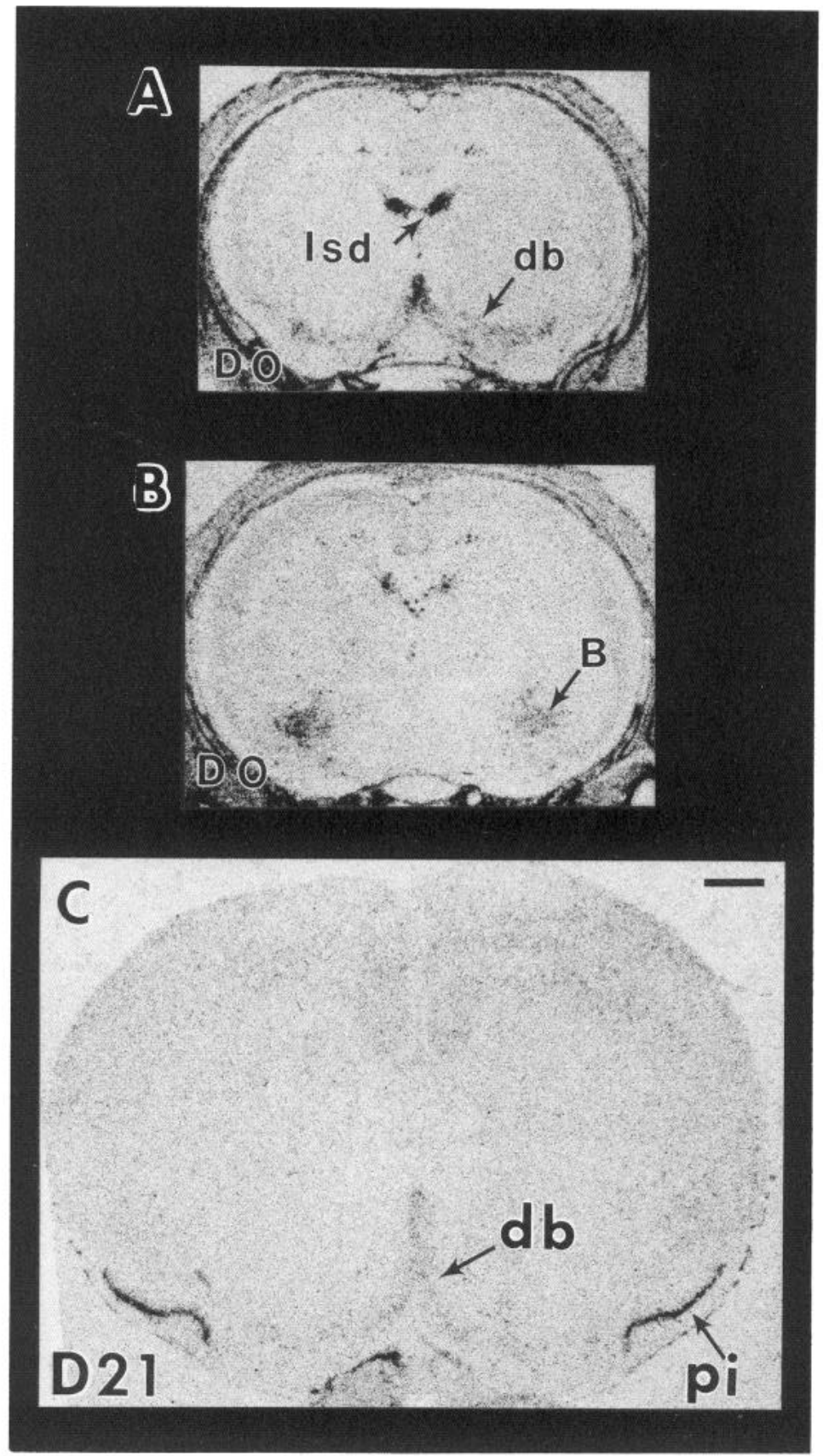

Figure 8. IGF-I mRNA localization in basal forebrain nuclei from D0 to D21: film autoradiographs of coronal sections through the forebrain of $\mathrm{D} 0(A$ and $B$ ) and D21 $(C)$ rats. $B$, Nucleus basalis of Meynert; $d b$, nuclei of the d;agonal band of Broca (both vertical and horizontal limbs); $l s d$, dorsal lateral septal nuclei; $p i$, piriform cortex. Scale bar, $1 \mathrm{~mm}$.

ating granule cells traversing the molecular layer are IGF-I positive and retain this immunoreactivity for a brief time after arriving in the internal granule layer. Glial cells and processes of the molecular layer also showed IGF-I immunoreactivity from D4 through D15-18 (Andersson et al., 1988). One interpretation of the finding that IGF-I immunoreactivity and mRNA are both abundant in developing Purkinje neurons while IGF-I immunoreactivity but not mRNA is found in other cerebellar cortical cells is that IGF-I is synthesized and secreted by Purkinje cells and then internalized by granule or glial cells in contact with Purkinje soma or processes-particularly the Purkinje dendrites that pervade the molecular layer. IGF-I released from Purkinje dendrites would be in a position to act on migratory, axon-sprouting granule cells or on other elements present in the molecular layer at this time of development, including the Purkinje dendrites themselves. IGF-I binding sites have been demonstrated in the adult cerebellar molecular layer (Bohannon et al., 1988; Lesniak et al., 1988), and IGF-I receptor mRNA is found in both granule and Purkinje cells during this postnatal period (Bondy, unpublished observations).

Detailed analysis of the process of synapse maturation has shown that "development of dendritic branches accompanies the elaboration of the particular type of axonal plexus that will become synaptically related," leading to the suggestion that "the patterns of the dendritic tree and of the afferent axonal-end branches derive from mutual interactions of the growing den- 

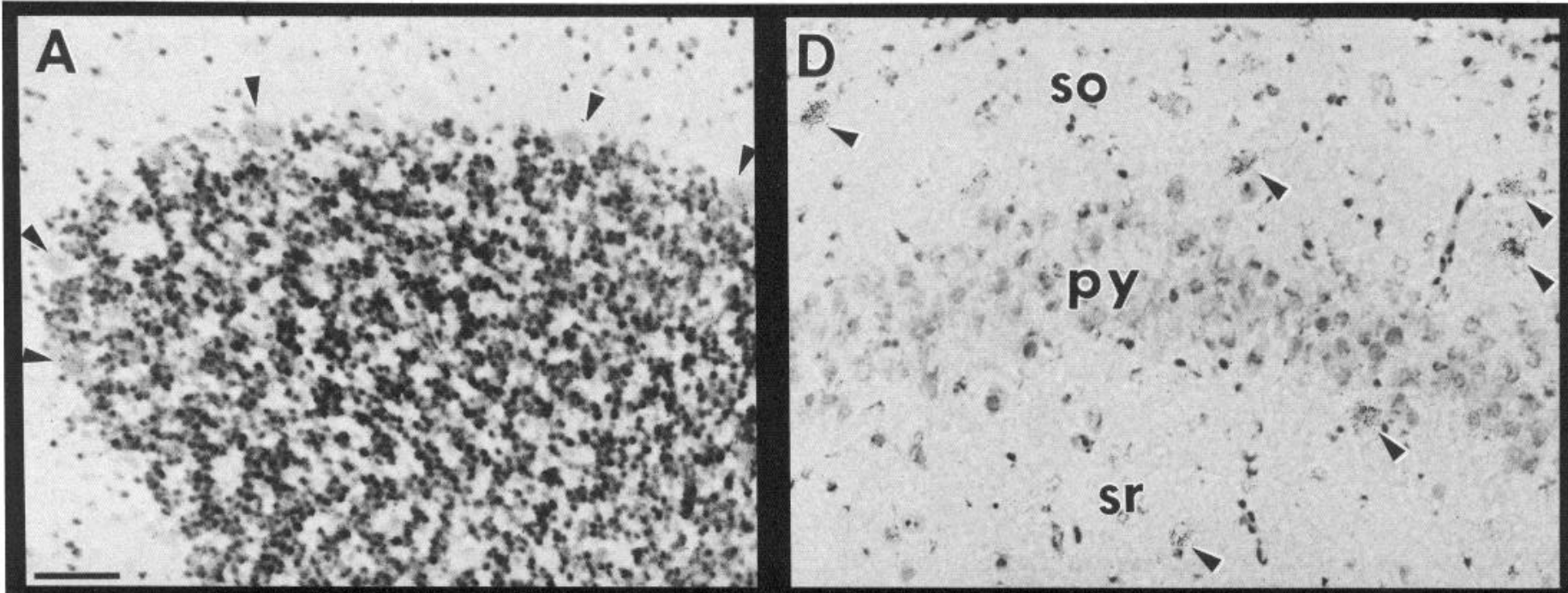

B.
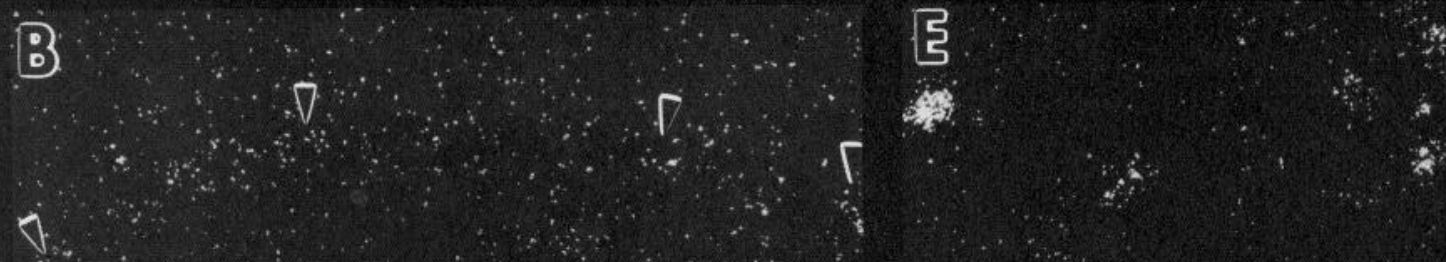

$\Delta$
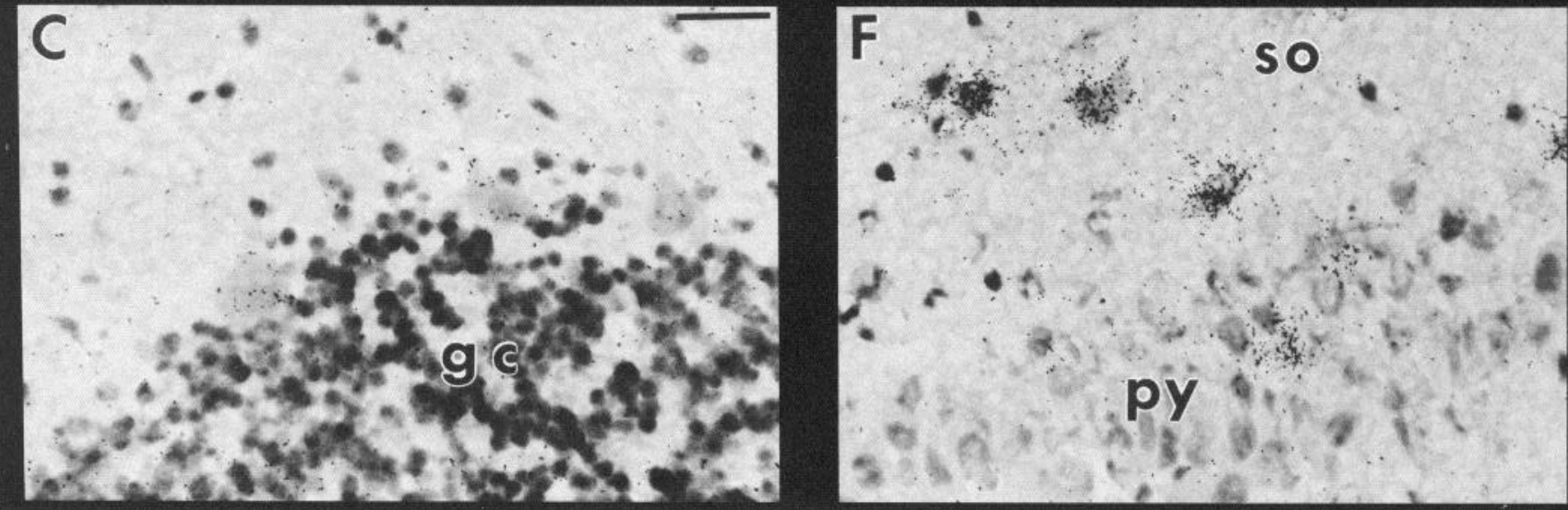

Figure 9. IGF-I mRNA localization in the D60 cerebellar cortex $(A-C)$ and D10 hippocampus $(D-F)$. $A$ and $B$ show matched bright- and darkfields, and $C$ shows a high-magnification view of the same section. These cerebellar sections were hybridized in a separate experiment, but under identical conditions and exposed for the same amount of time as those shown in Figure 1. Under these conditions, Purkinje cell IGF-I mRNA hybridization signal is just barely above background levels in the D60 cerebellum. With more prolonged exposure, it is possible to detect IGF-I mRNA at significantly greater than background levels in adult Purkinje cells, but under the same conditions, the hybridization signal from immature Purkinje cells is grossly overexposed. Arrowheads in $A$ and $B$ point out some individual Purkinje cells. $D-F$ show IGF-I mRNA localized in nonpyramidal cells in the CA1 field of Ammon's horn in a D10 rat brain. These cells are present in the strata oriens (so) and radiatum (sr). An occasional IGF-I mRNA-positive cell is embedded in the pyramidal cell layer $(F)$. Arrowheads in $D$ point out labeled cells. Scale bars: $A, B, D$, and $E, 50 \mu \mathrm{m} ; C$ and $F, 25 \mu \mathrm{m}$. 
dritic and axonal branches" (Morest, 1969). Given the timing and specific sites of neuronal IGF-I mRNA synthesis, IGF-I becomes a likely candidate as a growth factor involved in the interaction of dendritic and axonal processes in the formation of system-specific synapses.

\section{References}

Addison WHF (1911) The development of the Purkinje cells and the cortical layers in the cerebellum of the albino rat. J Comp Neurol 21: 459-487.

Aizenman $Y$, de Vellis $J$ (1987) Brain neurons develop in a serum and glial free environment: effects of transferrin, insulin, insulin-like growth factor-I and thyroid hormone on neuronal survival, growth and differentiation. Brain Res 406:32-42.

Altman J (1972) Postnatal development of the cerebellar cortex in the rat. II. J Comp Neurol 145:399-464.

Andersson IK, Edwall D, Norstedt G, Rozell B, Skottner A, Hansson H-A (1988) Differing expression of insulin-like growth factor I in the developing and adult rat cerebellum. Acta Physiol Scand 132: 167-173.

Arango V, Scalia F (1984) Afferent connections of the anterior pretectal nucleus. Soc Neurosci Abstr 10:60.

Ayer-le Lievre C, Stahlbom P-A, Sara VR (1991) Expression of IGF-I and -II mRNA in the brain and craniofacial region of the rat fetus. Dev 111:105-115.

Bastiani MJ, Harrelson AL, Snow PM, Goodman CS (1987) Expression of fasciclin I and II glycoproteins on subsets of axon pathways during neuronal development in the grasshopper. Cell 48:745-755.

Baxter RC (1986) The somatomedins: insulin-like growth factors. Adv Clin Chem 25:49-115.

Bohannon NJ, Corp ES, Wilcox BJ, Figlewicz DP, Dorsa DM, Baskin DG (1988) Localization of binding sites for IGF-I in the rat brain by quantitative autoradiography. Brain Res 444:205-213.

Bondy CA, Chin E (1991) IGF-I mRNA localization in sympathetic and trigeminal target zones during rat embryonic development. In: Molecular biology and physiology of insulin and insulin-like growth factors (LeRoith D, Raizada M, eds), pp 431-437. New York: Plenum.

Bondy CA, Werner II, Roberts CT, LeRoith D (1990) Cellular pattern of IGF-I and type I IGF receptor gene expression in early organogenesis: comparison with IGF-II gene expression. Mol Endocrinol 4: 1386-1398.

Bourrat F, Gotow T, Sotelo C (1989) Development of the rat inferior olive: migratory routes, formation of afferent and efferent connections. In: The olivocerebellar system of motor control (Strata P, ed), pp 128-147. Berlin: Springer.

Caroni P, Grandes P (1990) Nerve sprouting in innervated adult skeletal muscle induced by exposure to elevated levels of insulin-like growth factors. J Cell Biol 110:1307-1313.

Cox KH, DeLeon DV, Angerer LM, Angerer RC (1984) Detection of mRNAs in sea urchin embryos by in situ hybridization using asymmetric RNA probes. Dev Biol 101:485-502.

Daughaday WII, Rotwein P (1989) Insulin-like growth factors I and II. Peptide, mRNA and gene structures, serum and tissue concentrations. Endocr Rev 10:68-91.

De la Monde SM, Federoff HJ, Ng S-C, Grabczyk E, Fishman MC (1989) GAP-43 gene expression during development: persistence in a distinctive set of neurons in the mature central nervous system. Dev Brain Res 46:161-168.

DiCiccio-Bloom E, Black IB (1988) Insulin growth factors regulate the mitotic cycle in cultured rat sympathetic neuroblasts. Proc Natl Acad Sci USA 85:4066-4070.

Gesteland RC, Yancey RA, Farbman AI (1982) Development of olfactory receptor neuron selectivity in the rat fetus. Neuroscience 7 : 3127-3136.

Graziadei PPC, Monti-Graziadei GA (1978) Continuous nerve cell renewal in the olfactory system. In: Handbook of sensory physiology, Vol 9, Development of sensory systems (Jacobson M, ed), pp 5583. Berlin: Springer.
Hansson H-A (1990) Insulin-like growth factor-I: aspects of its cellular localization and dynamic changes. Curr Med Lit 5:3-10.

Higgins GA, Wilson MC (1987) In situ hybridization for mapping the neuroanatomical distribution of novel brain mRNAs. In: In situ hybridization: applications to neurobiology (Valentino KL, Eberwine JH, Barchas JD, eds), pp 145-162. New York: Oxford UP.

Hockfield S, McKay RDG (1983) A surface antigen expressed by a subset of neurons in the vertebrate nervous system. Proc Natl Acad Sci USA 80:5758-5761.

Lesniak MA, Hill JA, Kiess W, Rojeski M, Pert CB, Roth J (1988) Receptors for IGF-I and -II: autoradiographic localization in rat brain and comparison to receptors for insulin. Endocrinology 123:20892099.

Levitt P (1984) A monoclonal antibody to limbic system neurons. Science 223:299-301.

Lowe WL Jr, Lasky SR, LeRoith D, Roberts CT Jr (1988) Distribution and regulation of rat IGF-I mRNA encoding alternative carboxyterminal E-peptides: evidence for differential processing and regulation in liver. Mol Endocrinol 2:528-535.

McMorris FA, Dubois-Dalcq M (1988) Insulin-like growth factor I promotes cell proliferation and oligodendroglial commitment of rat glial progenitor cells developing in vitro. J Neurosci Res 21:199-209.

Morest DK (1969) The differentiation of cerebral dendrites: a study of the post-migratory neuroblast in the medial nucleus of the trapezoid body. Z Anat Entwicklungsgesch 128:271-289.

Ramon y Cajal S (1911) IIistologie du systeme nerveux de l'homme et des vertebres. Madrid: Instituto Ramon y Cajal.

Recio-Pinto E, Rechler MM, Ishii DN (1986) Effects of insulin, insulin-like growth factor-II and nerve growth factor on neurite formation and survival in cultured sympathetic and sensory neurons. $J$ Neurosci 6:1211-1219.

Rotwein P, Burgess SK, Milbrandt JD, Krause JE (1988) Differential expression of insulin-like growth factor genes in rat central nervous system. Proc Natl Acad Sci USA 85:265-269.

Saneto RP, Low KG, Melne MH, de Vellis J (1988) Insulin/insulinlike growth factor-I and other epigenetic modulators of myelin basic protein expression in isolated oligodendrocyte progenitor cells. J Neurosci Res 21:210-219.

Sara VB, Hall K, von Holtz H, Humbel R, Sjogren B, Wetterberg L (1982) Evidence for the presence of specific receptors for IGF-I and IGF-II and insulin throughout the adult human brain. Neurosci Lett 34:39-44.

Sara VR, Carlsson-Skwirut C, Andersson C, Hall E, Sjogren B, Holmgren A, Jornvall H (1986) Characterization of somatomedins from human fetal brain: identification of a variant form of IGF-I. Proc Natl Acad Sci USA 83:4904-4907.

Scheibel AB, Scheibel ME (1978) The development of the somatosensory thalamus in mammals. In: Handbook of sensory physiology, Vol 9 (Jacobson M, ed), pp 239-278. New York: Springer.

Shimatsu A, Rotwein P (1987) Mosaic evolution of the insulin-like growth factors. J Biol Chem 262:7894-7900.

Singer RH, Lawrence JB, Rashtchian L (1987) Toward a rapid and sensitive in situ hybridization methodology using isotopic and nonisotopic probes. In: In situ hybridization: applications to neurobiology (Valentino KL, Eberwine JH, Barchas JD, eds), pp 71-96. New York: Oxford UP.

Underwood LE, D'Ercole AJ, Clemmons DR, Van Wyk JJ (1988) Paracrine functions of somatomedins. Clin Endocrinol Metab 15:59 78.

Werner H, Woloschak M, Adamo M, Shen-Orr Z, Roberts CT, LeRoith D (1989) Developmental regulation of the rat insulin-like growth factor I receptor gene. Proc Natl Acad Sci USA 86:7451-7455.

Werther GA, Abate M, Hogg A, Cheeseman H, Oldfield B, Hards D, Hudson P, Power B, Freed K, Herington AC (1990) Localization of IGF-I mRNA by in situ hybridization-relationship to IGF-I receptors. Mol Endocrinol 4:773-778.

Westrum LE (1975) Electron microscopy of synaptic structures in olfactory cortex of early postnatal rats. J Neurocytol 4:713-732. 